

\title{
Point Intercept and Line Intercept Methods for Aquatic Plant Management
}

By John Madsen

PURPOSE: The purpose of this technical note is to apply point intercept and line intercept quantification methods to aquatic plant communities, statistically analyze the resulting data, and apply the data to aquatic plant management research and operations.

BACKGROUND: Quantitative methods typically are not used to evaluate the success of aquatic plant management operations; in fact, many research and demonstration projects fail to collect data suitable for statistical analysis. Despite this oversight, the collection and analysis of quantitative data are important for the following four reasons (Madsen and Bloomfield 1993):

a. Quantitative data are an objective measure of plant distribution and abundance.

b. Quantification allows rigorous statistical analysis (both spatial and temporal) of plant community trends; thereby supporting assessments of management technique effectiveness.

c. Quantification of vegetation, as part of an evaluation program, may eliminate the use of ineffective techniques or unneeded control in a given management approach.

d. Quantification allows individuals other than the observer to evaluate the data.

These are convincing reasons to employ quantitative methods for measuring aquatic plant distribution or abundance for both research and operational programs.

The use of quantitative methods for aquatic plants has not become as standardized as other components in the aquatic ecosystem, such as biotic (e.g., fish) or physical components (e.g., water chemistry) (APHA 1995, Lind 1979, Wetzel and Likens 1991). Even when considering aquatic biomass sampling, which is a widely accepted means of quantifying aquatic plant communities, there is considerable divergence in implementation of the technique that may result in data incomparability (Dennis and Isoms 1984, Madsen 1993, Spencer and Whitehand 1993). While biomass sampling will provide accurate estimates of plant abundance on both whole-lake (Madsen and Barko 1997) and study plot (Getsinger et al. 1997) bases, it is very costly, time- and labor-intensive, and not suited for measuring all aspects of the plant community.

Presence/absence techniques can be used to rapidly collect large quantities of data. These "presence-" based techniques involve no samples to analyze after a day in the field, and have a relatively unequivocal end point - the plant species is either at the given location, or not. Two techniques utilizing this approach are point intercept and line intercept methods. While these methods are widely used in terrestrial plant ecology (Grieg-Smith 1983, Kershaw 1973), their use is not as commonplace in aquatic plant ecology. In addition to being more rapid and less costly to perform than biomass sampling, they are less sensitive to interannual variations in plant abundance or seasonal changes, more readily adapted to larger areas, and more sensitive to species diversity. The point intercept method is readily adapted to whole-lake or large plot assessments, utilizing Global Positioning System (GPS) technology. The transect method is best used in evaluating study plots, though it has been used in whole-lake studies in the past (Madsen et al. 1996). The transect 
method presented has been used in previous studies (Madsen et al. 1994); however, a number of variations in the use of transects have been reviewed elsewhere (Titus 1993).

METHODS: The principle of these two intercept methods is relatively simple, having been widely used in terrestrial plant and animal ecology survey techniques. Spot observations are made at a large number of points, and statistically compared using the assumptions of a binomial distribution. The statistical tests used, therefore, are Chi-square and related comparisons, rather than parametric statistics based on a normal distribution. While the math may be complicated, the procedures are relatively straightforward and easy to do.

- Point Intercept Sampling. The objective of point intercept is to make measurements at regularly spaced, preselected or defined locations and to avoid subjectively selecting locations in the field. These data can then be used in various analyses. Pre-selecting or defining points and finding them in the field are critical parts of this approach; they may be performed manually or with the help of a Global Positioning System (GPS), a geographic information system (GIS), or a desktop mapping software package. Most GIS or mapping packages can generate grid points at a user-specified spacing. These points can then be entered into the navigation software of many GPS systems to rapidly find the points in the field. Alternatively, the data point positions can be printed onto data sheets and the user can navigate from one point to another if the option of downloading waypoints to the GPS unit is not available. If no facilities for generating grid points are available, or the waypoints are found to be erroneous once the user is in the field (which has been known to happen), it is possible to start at one end of the study site, and navigate from one grid point by adding the correct interval between the points.

The potential size of a study plot may be determined by the horizontal positioning accuracy of the GPS unit. Low-cost GPS units can locate points within $30 \mathrm{~m}$; this may be adequate for doing wholelake studies where the distance between points is much larger than the horizontal error. Smaller study sites or study plots with a small point-to-point distance would require better positioning accuracy and a real-time differentially corrected GPS, capable of horizontal accuracy of $5 \mathrm{~m}$ or less.

A few additional suggestions for this process are as follows:

a. Use the UTM coordinate system rather than a degree-based system, because it is set out in linear distances north and east of an origin point. This will make it much easier to move from point to point.

b. Make the grid interval between points a round number (e.g., $50 \mathrm{~m}$ rather than $67 \mathrm{~m}$ ), which will make the mental arithmetic from point to point much easier. Round to the next smaller even grid interval and do more points. While more sophisticated GPS systems allow the grid locations to be stored as "waypoints," most entry-level devices and even many better systems with real-time differential correction do not allow the storage of a large enough number of waypoints.

c. Err on the side of too many points. Points can always be omitted in the field, if necessary due to time constraints.

Use the downloaded coordinate system to develop data sheets, or use a portable computer or tablet database with coordinates and spaces to enter species presence/absence data and other desired 
environmental data. While many parameters may be included (e.g., bottom type or Secchi disk depth), the most critical one to be included in all surveys is water depth.

Once on the lake with the GPS system operational, navigate from point to point in a regular pattern. At each point, measure and record selected environmental parameters in their appropriate locations on the data sheet, and observe which species are present at the sample point. Record present species as a "1," and species not present as " 0 ." Species observations can be made directly from the surface, using a view scope (e.g., "bathyscope"), or by the use of a rake or other collection device if water is too turbid or deep for direct observation. Since this is a "point" method, it is important to be consistent in sampling the same relative area at each point. If direct visual observations are used, monitor a small area alongside the boat (e.g., an imaginary 3-m by 3-m quadrat). If a rake toss is being used, consistently make the same number of tosses per site. Theoretically, the most pure application of the point intercept method would be to use a staff, and record only those species touching the staff throughout the depth profile of the point (e.g., a leaf intercept). However, this approach could slow the survey down, and is not always practical in deep or turbid lakes.

One other consideration for all field surveys is that plant voucher specimens should be taken. Take one set of vouchers of each species for a given lake, and have these verified by a taxonomic expert. While this may seem a wasteful effort to nonbotanists, in the long run it will provide a valuable definitive record of the species present in the lake (Hellquist 1993).

Data entry and analysis of point intercept data and line intercept data are discussed together, as they are entered and analyzed in similar fashion.

- Line Intercept Sampling. Line intercept methods have been more widely used in terrestrial, wetland, and aquatic systems than the point intercept method (Bauer 1943, White 1965, Schmid 1965). The line intercept method requires less technology for application, and seems more intuitively obvious to most people than the point intercept method. Generally, several transects are deployed in the study area, or around the littoral zone of the study lake, to determine the percent occurrence of the species in the plant community. Line transects have been used for many purposes, including directly measuring cover of a target species, developing set intervals for the use of a quadrat, and marking set line intervals in which species presence is recorded (Grieg-Smith 1983, Madsen et al. 1996, Titus 1993, Getsinger et al. 1997). Set line intervals will be used to determine species presence in this note.

Prepare a transect line with markings every $1 \mathrm{~m}$. Use a 1/4-in. or 3/8-in. nylon braided rope, preferably a bright color such as yellow. The markings can either be permanent marker or flagging, but fluorescent flagging is preferable due to greater visibility. Use an alternate color for the 5- and 10-m intervals to keep track of locations on the transect. The transect can either be a set length (e.g., $100 \mathrm{~m}$ ), or the length between permanent end points, in the case of permanent transects.

Species presence and absence can be evaluated from a boat or raft, by wading, or by snorkeling or SCUBA diving; depending on the water depth, species of interest, and other pertinent factors. Typically, the best results in water depths greater than $3 \mathrm{ft}$ will be obtained by snorkeling or SCUBA diving. Observers are encouraged to follow appropriate safety requirements of both their agency and OSHA if data are collected in the water. If data are collected by snorkelers or SCUBA divers, data 
sheets can be printed on white acetate sheets (e.g., Xerox Never Tear Paper, Xerox Corp., Rochester, NY).

Species present should be recorded for each line segment, as was done for the point sampling. Species are considered present in a given line segment if they intersect the plane of the line segment from the bottom to the surface. While depth information is helpful, it is difficult to estimate depths and awkward to measure depths while snorkeling or SCUBA diving, so typically these measurements are not done for line intercept transects at each interval. Rather, the depths at the beginning and end of the transects should be recorded, and the important depth transitions can be recorded by the boat laying out the transect if this information is desired.

Data are recorded on data sheets such as that shown in Figure 1. For each 1-m interval, all species or target species are marked if they are present (1) or absent (0) between the two marks, below the line; in other words, if the species crosses or intercepts the vertical plane made by the line segment. Additional data, such as water depth or sediment type, can also be recorded for analysis of correspondence between species occurrence and environmental conditions. For a given study, more than one transect should be utilized. If the study involves a treatment effect versus reference, use 400 intervals (preferably as four 100-m transects) for each plot. The more transects or intervals used, the greater the statistical power in subsequent data analyses. For quantification of plants in a lake, stratified-random deployment of transects around the perimeter of the lake is recommended, and transects are generally deployed perpendicular to shore. However, transect methods can be adapted for many study purposes and objectives (Titus 1993).

Data Entry. Data are entered to a PC spreadsheet or database program using a "1" for points or intervals with species present, and a " 0 " for intervals in which species are absent. Data entry will also facilitate calculation of indices of species richness, presence/frequency of classes of plants (dicots, monocots, native, exotic), and can also be used to construct maps of vegetation if transect locations are known.

In addition to the species present or absent, pertinent environmental data (e.g., water depth) collected at each point or segment should be entered, as well as classification data for each point or segment, like point or segment number, transect number, and latitude and longitude (for points).

As part of the database or spreadsheet file, summary statistics that will be relevant for statistical analysis can also be computed for each case. For instance, the sum of all species present gives an estimate of diversity. The number of exotic or native species per point or segment can also be calculated easily with a spreadsheet file. 


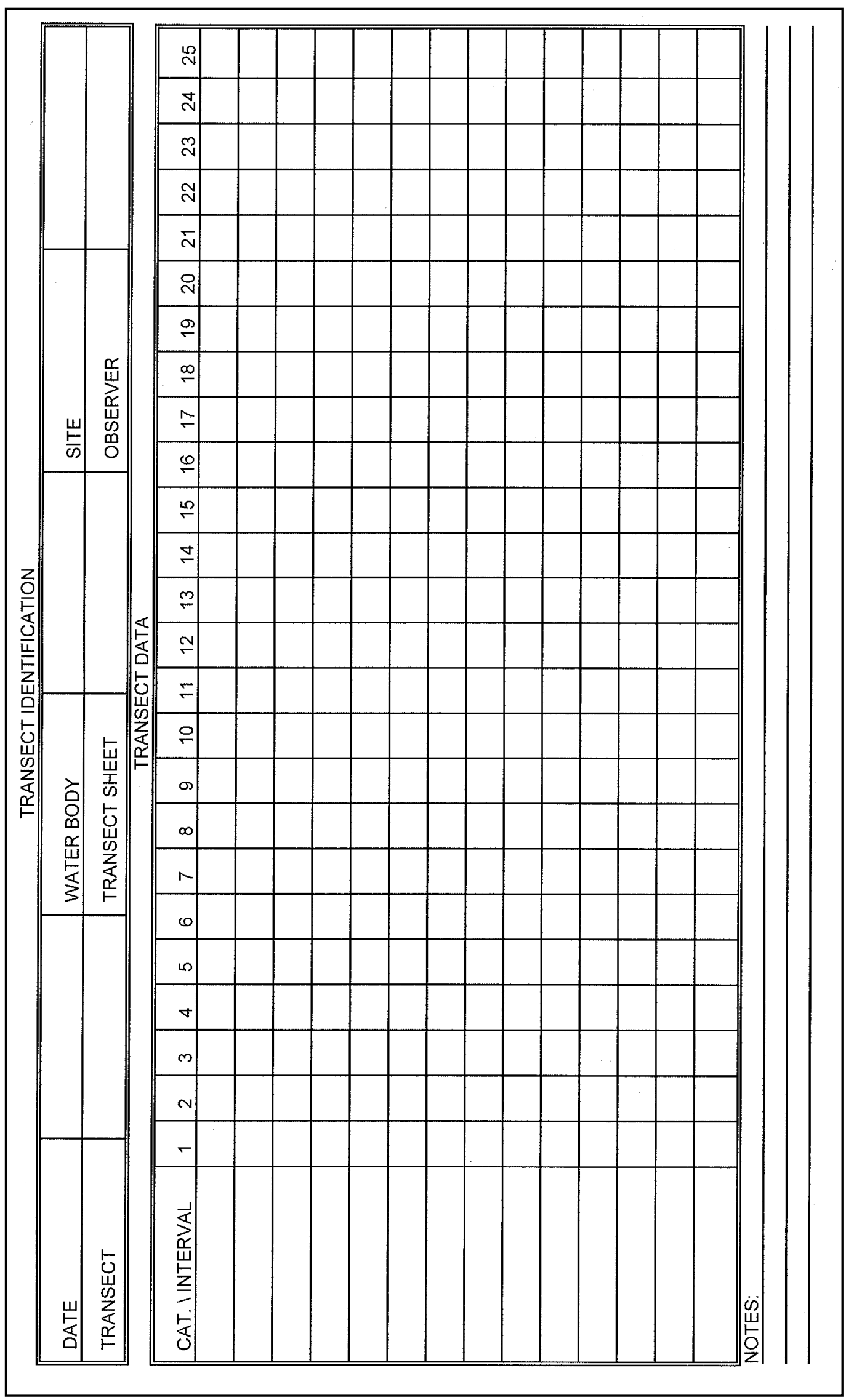

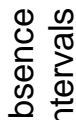

tั

ปั

क ष

응 홍

ญ드

苟

$\stackrel{0}{\risingdotseq}$

든하

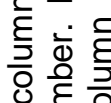

过

西乒

엉

$\stackrel{\Phi}{.}$.

$\stackrel{0}{\square}$

๙

⿻ 3

응

ญํํ름

to

$\geq \stackrel{\Phi}{\rightleftarrows}$

응

정잉



क

용

드능

홍 응

O

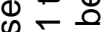

뜽 쥬

(1) के

$\stackrel{\Xi}{ } . \frac{\Phi}{\infty}$

屯ั

$\frac{\widetilde{\sigma}}{\omega} \stackrel{\widetilde{\pi}}{\leftrightarrows}$

疍

응

응

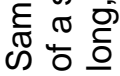

힌 
- Data Analysis. Data analysis can be as simple as counting the number of intercepts (derived from either point intercepts or line interval intercepts) in which species are present, and dividing by the total number of intercepts examined, to determine the frequency of occurrence. For large numbers of intercepts, this provides a rough approximation of percent cover. Before-and-after analyses or comparisons between points or transects for a given species can be made using a two-by-two or chisquare analysis (see any introductory statistics books for detail, e.g., Snedecor and Cochran (1980)) using the actual numbers of intervals with and without the species. Use the actual number of observations rather than frequencies (or percentages) for the statistical test. For instance, a given study of the effectiveness of herbicide $X$ was set up in one plot in which four 100-m transects were used as a treatment plot, and a similar setup was used for a reference plot. Pretreatment transect counts found 320 intervals with the target species, and 80 without. Six weeks after treatment, the analysis noted 200 intervals with the target species, and 200 without. The two-by-two analysis for the treatment plot would look like Table 1. The Chi-square analysis, using the actual interval counts, indicated a significant reduction in the presence (or frequency of cover) of the target species, using the Pearson】s Chi-square test $(\mathrm{p}<0.001)$. This statistical test therefore indicated a significant reduction in the target species following an herbicide treatment. To verify that this is due to an herbicide treatment, a similar analysis should be performed on the reference plot.

\section{Table 1}

Two-by-Two Comparison of Pre- and Posttreatment Counts of Line Transect Intervals with and without Target Species ${ }^{1}$

\begin{tabular}{||l|l|l|l||}
\hline \hline Count & $\begin{array}{l}\text { Intervals with Target } \\
\text { Species }\end{array}$ & $\begin{array}{l}\text { Intervals without Target } \\
\text { Species }\end{array}$ & Totals \\
\hline \hline Pretreatment & 320 & 80 & 400 \\
\hline Posttreatment & 200 & 200 & 400 \\
\hline Total & 520 & 280 & 800 \\
\hline \hline
\end{tabular}

Species diversity should be analyzed using parametric statistics such as a T-test (for two samples) or a one-way ANOVA for three or more sample periods. Use of these techniques will be demonstrated in the following two applications.

\section{APPLICATIONS}

- Point Intercept Method: Big Muskego Lake, WI. Big Muskego Lake is a large, shallow lake that was very turbid with low diversity and an abundance of aquatic plants before 1996. After reviewing possible management options, it was decided that a drawdown for one complete year would reduce the abundance of Eurasian watermilfoil (Myriophyllum spicatum L.) and promote the establishment and expansion of native plant species. A pretreatment survey was performed in 1995, with the posttreatment survey in 1997. A total of 213 points were selected for each survey, at grid intervals of $200 \mathrm{~m}$ between points (Figure 2). 




Figure 2. Point intercept sample locations in Big Muskego Lake, WI

- Species Frequency. To test whether the drawdown was effective in reducing the distribution of the exotic nuisance plant Eurasian watermilfoil, a Chi-square test on a two-by-two table was performed (Table 2). According to the Chi-square statistic, Eurasian watermilfoil distribution in the lake dropped significantly $(\mathrm{p}<0.001)$. 


\begin{tabular}{|c|c|c|c|}
\hline \multicolumn{4}{|c|}{$\begin{array}{l}\text { Table } 2 \\
\text { Two-by-Two Comparison of Pre- Drawdown (1995) and Post-Drawdown (1997) Point } \\
\text { Intercept Survey Data on Eurasian Watermilfoil Occurrence in Big Muskego Lake }{ }^{1}\end{array}$} \\
\hline Year & $\begin{array}{l}\text { Eurasian Watermilfoil } \\
\text { Present }\end{array}$ & $\begin{array}{l}\text { Eurasian Watermilfoil } \\
\text { Absent }\end{array}$ & $\begin{array}{l}\text { Row Total (Total Points } \\
\text { Observed per Year) }\end{array}$ \\
\hline 1995 & $191(90 \%)$ & $22(10 \%)$ & 213 \\
\hline 1997 & $75(36 \%)$ & $134(64 \%)$ & 209 \\
\hline Totals & 266 & 156 & 422 \\
\hline
\end{tabular}

Waterfowl biologists expressed the hope that the drawdown would stimulate the germination of emergent plant seeds, and establish more cover for waterfowl. A Chi-square analysis of cattail (Typha spp.) frequency was performed (Table 3). The frequency of cattail increased significantly in the lake after drawdown $(\mathrm{p}<0.0001)$.

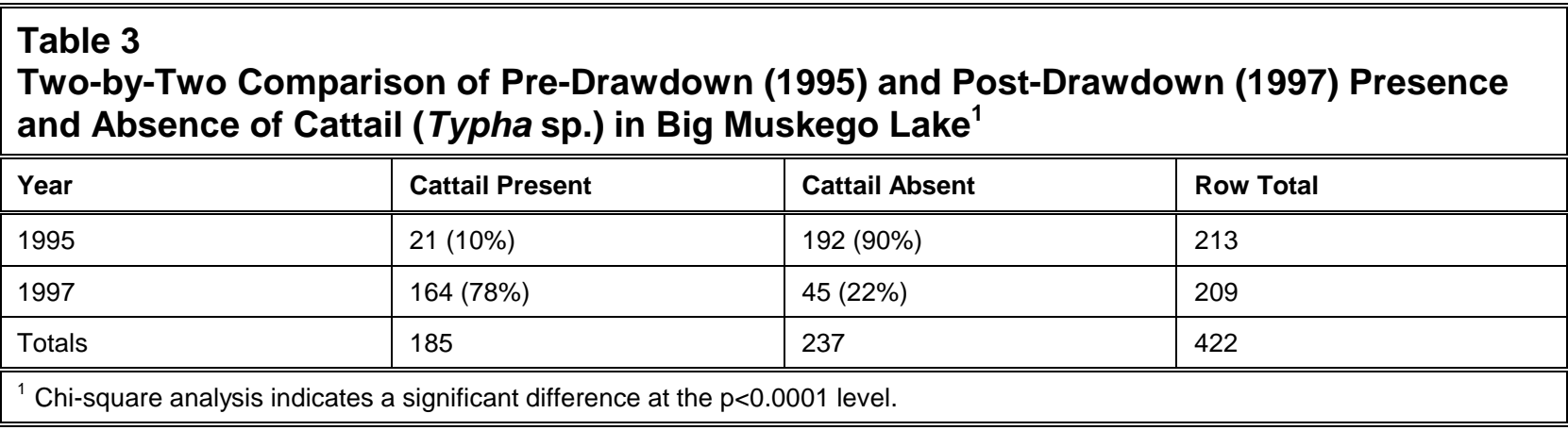

- Species Diversity. Data comparing diversity measures can be analyzed using a t-test. Since there are over 200 points per survey date in the Big Muskego Lake data set, this test should provide a robust indicator of change. Analysis of total number of species (All Species, Figure 3) indicated that drawdown significantly increased the average number of species per point. The average number of native species also increased significantly (Native Species Only, Figure 3), indicating a significant increase in native plant diversity. In each case, the t-test was highly significant $(p<0.0001)$. Point intercept is a very sensitive measure of both species frequency and diversity in an aquatic system, and can accurately detect statistically significant changes of as little as 5 to 10 percent in frequency.

- Mapping. Using the point intercept data, a variety of maps can also be generated using either a GIS or desktop mapping package, or another type of less expensive graphics software.

For instance, the water depth (in centimeters) for each sampling point on Big Muskego Lake could be shown on a base map of the lake (Figure 4). While this might be useful to many individuals, the same data can be used to make a surface plot, which is essentially a bathymetric map of the lake (Figure 5). Other environmental data can be graphed in either of these two formats. 


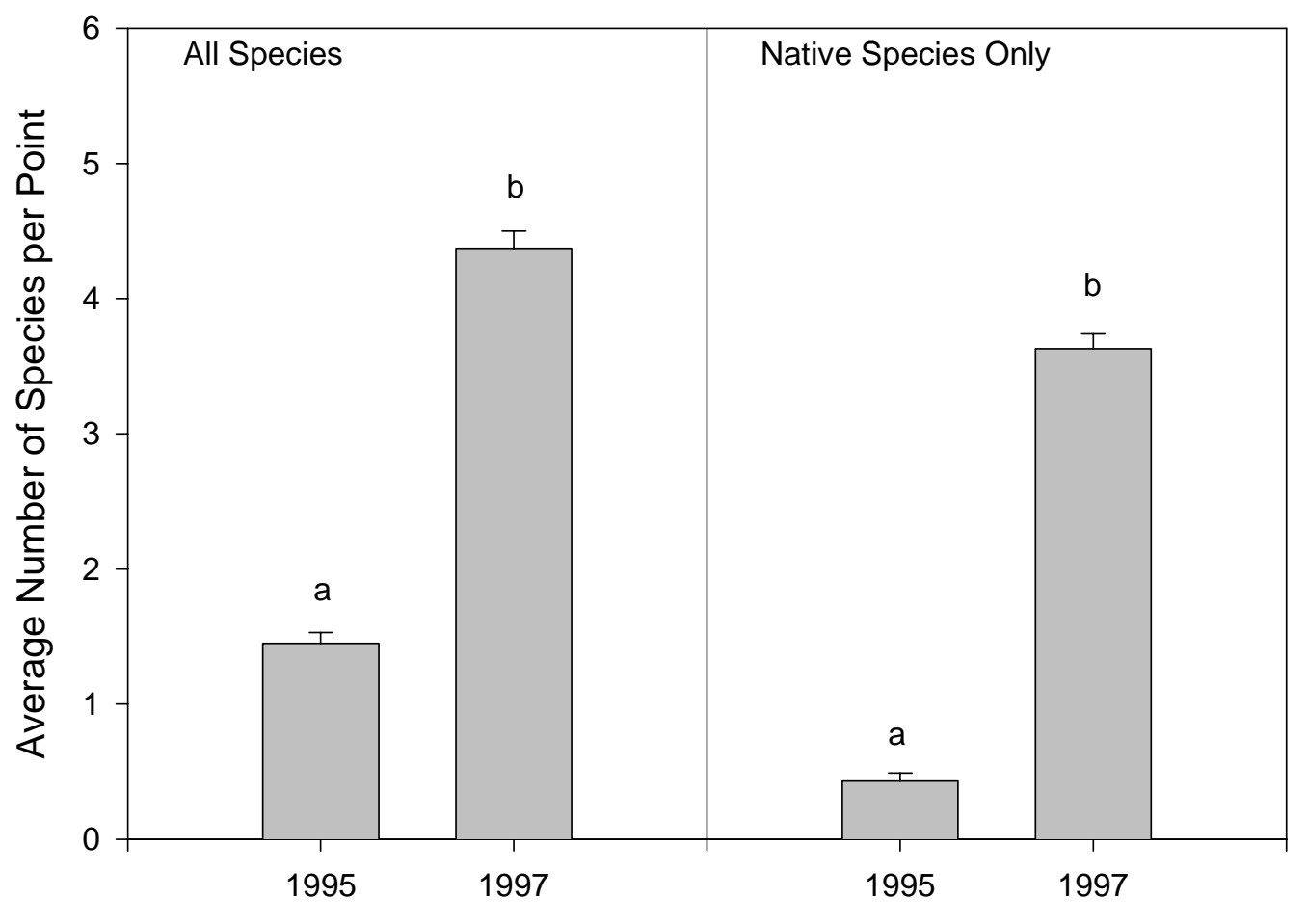

Figure 3. Species diversity of Big Muskego Lake as measured by average number of species per point (left) and average number of native species (right) in 1995 and 1997

A simple dot map showing the location of various species can also be generated in a similar manner. For instance, the locations of Eurasian watermilfoil from the 1995 survey can be easily mapped, which gives a rough distribution map (Figure 6). These data could also be plotted as presence isopleths or boundaries.

- Line Intercept Method: Lake Minnetonka, MN. Lake Minnetonka, located just west of the metropolitan area of Minneapolis, Minnesota, was first found to have Eurasian watermilfoil in 1986. Eurasian watermilfoil had become a considerable nuisance in some locations by 1989 (Smith, Barko, and McFarland 1991); however, it did not dominate all littoral zone areas of the lake. Two treatment sites (Phelps and Carsons Bays) and one reference site (Carman Bay) were examined (Figure 7). Each study plot was approximately 10 to 15 acres. In the center of each plot, five 100-m transects with marked intervals every $1 \mathrm{~m}$ were deployed perpendicular to shore, spaced $25 \mathrm{~m}$ apart. SCUBA divers recorded the plant species present in each 1-m interval of the transect to determine species distribution and diversity. Transects were evaluated in June 1994, before a triclopyr treatment, and in August 1994, six weeks after treatment. 




Figure 4. Map of water depth (in centimeters) from point intercept data collected during 1995 in Big Muskego Lake

- Species Frequency. Transect frequency data give better information on the distribution and diversity of plants than biomass data. Total plant frequency, measured as whether or not plants occurred in a given line interval, did not change at the reference site, but was significantly decreased at both treatment sites (Figure 8). However, plant occurrence only decreased from 100 percent to 85 percent, indicating that while this was a statistically significant decrease, native plants were still present in most of the sites sampled. 




Figure 5. Bathymetric contour map based on data from Figure 3

Eurasian watermilfoil distribution decreased significantly at both treatment sites, from approximately 70 percent before treatment to 0 percent after treatment (Figure 8). In fact, no rooted Eurasian watermilfoil was observed at either site after treatment, although floating Eurasian watermilfoil fragments were observed. In contrast, the distribution of Eurasian watermilfoil at the reference site actually increased. 


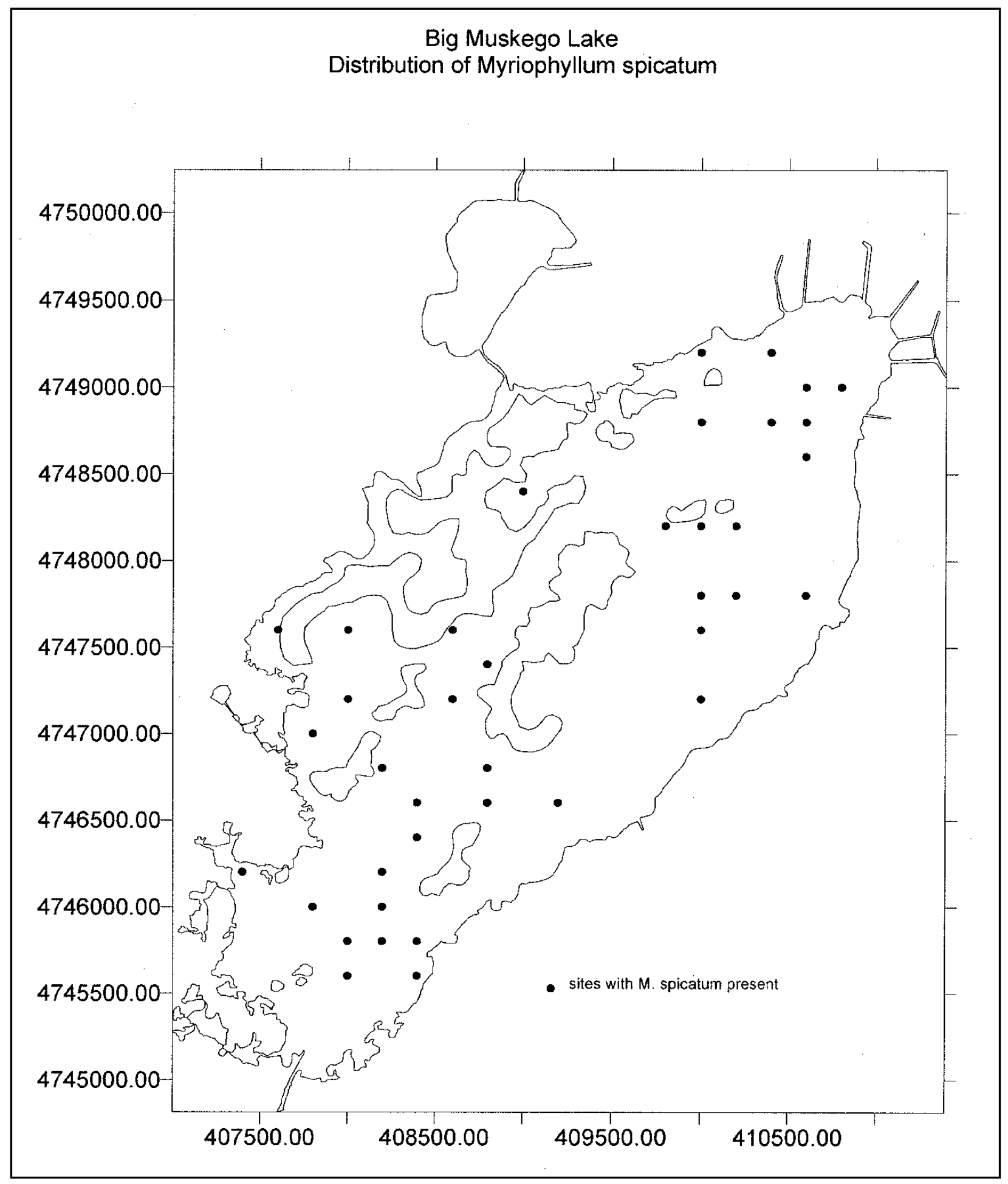

Figure 6. Distribution of Eurasian watermilfoil during 1995 in Big Muskego Lake 


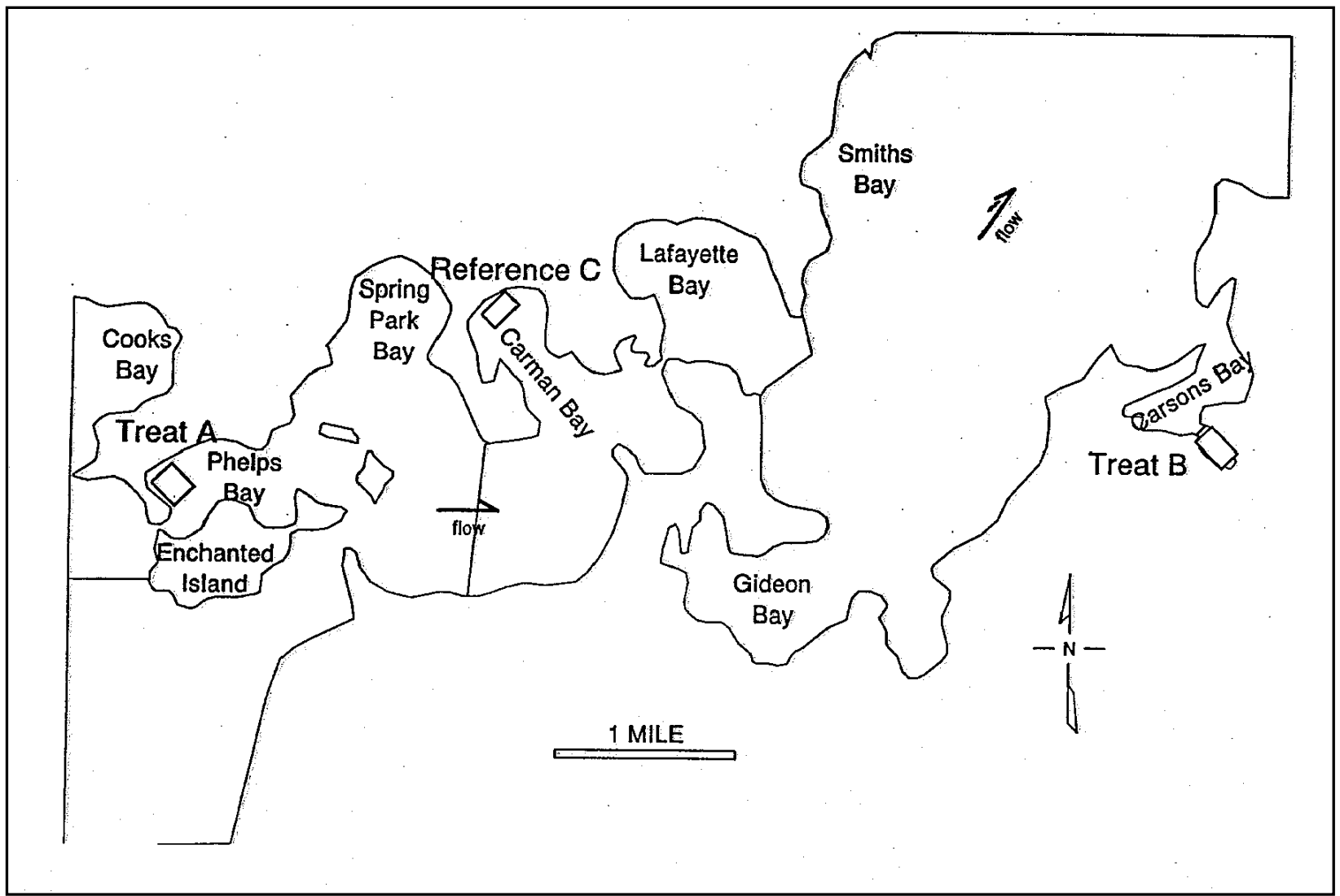

Figure 7. Location of the two study plots and one reference plot in Lake Minnetonka

Native plant coverage also decreased at both treatment sites, but only by 5 to 10 percent (Figure 8). In contrast, native plant coverage decreased from 60 percent in June to 30 percent in August at the reference site, where no herbicides were applied. The apparent contradiction with the increase in native plant biomass at this site may be explained through significant increase in biomass of a few species locally, and mortality of a few individuals that occurred throughout the bay. The decrease in native plant cover caused by the application of triclopyr was substantially less than observed in an untreated site.

- Species Diversity. Native plant diversity, as measured by average number of species per transect interval, decreased by almost 1.0 at both treatment sites (Figure 9). However, the diversity levels at the treatment sites were both above 1.0 after treatment, while the reference plot with dense Eurasian watermilfoil had average diversity of less than 0.5. Treatment with triclopyr at the full label rate may have caused the mortality of some native species. However, as was observed in the Pend Oreille River, native plant diversity and abundance will probably increase substantially next growing season, after the removal of Eurasian watermilfoil biomass (Getsinger et al. 1997).

- Other Applications. These methods can be used for many other purposes, such as routine monitoring of populations (Madsen et al. 1994), assessing spread of nonindigenous plant colonies (Madsen et al. 1991), and assessing the effectiveness of an aquatic plant management technique. While point sampling is typically better suited for whole-lake rather than plot applications, it can also be adapted for smaller plots. 




PRETREATMENT POSTTREATMENT

Figure 8. Percent frequency of observance along transects pre- (PRE) and posttreatment (POST) at the two treatment sites (PHELPS, CARSON) and the untreated reference (CARMEN (REF.)) site: total plant cover (bottom), Eurasian watermilfoil cover (middle), and native plant cover (top). Asterisks $\left.{ }^{*}\right)$ indicate a significant difference between pre- and post-treatment at the $p=0.05$ level using a chisquare test on a two-by-two table

Point intercept and line intercept techniques are powerful tools to quantitatively assess plant communities, target plant populations, and native plant diversity. In combination with other assessment techniques, they can provide an accurate, objective, and verifiable picture of the natural resource being managed. 


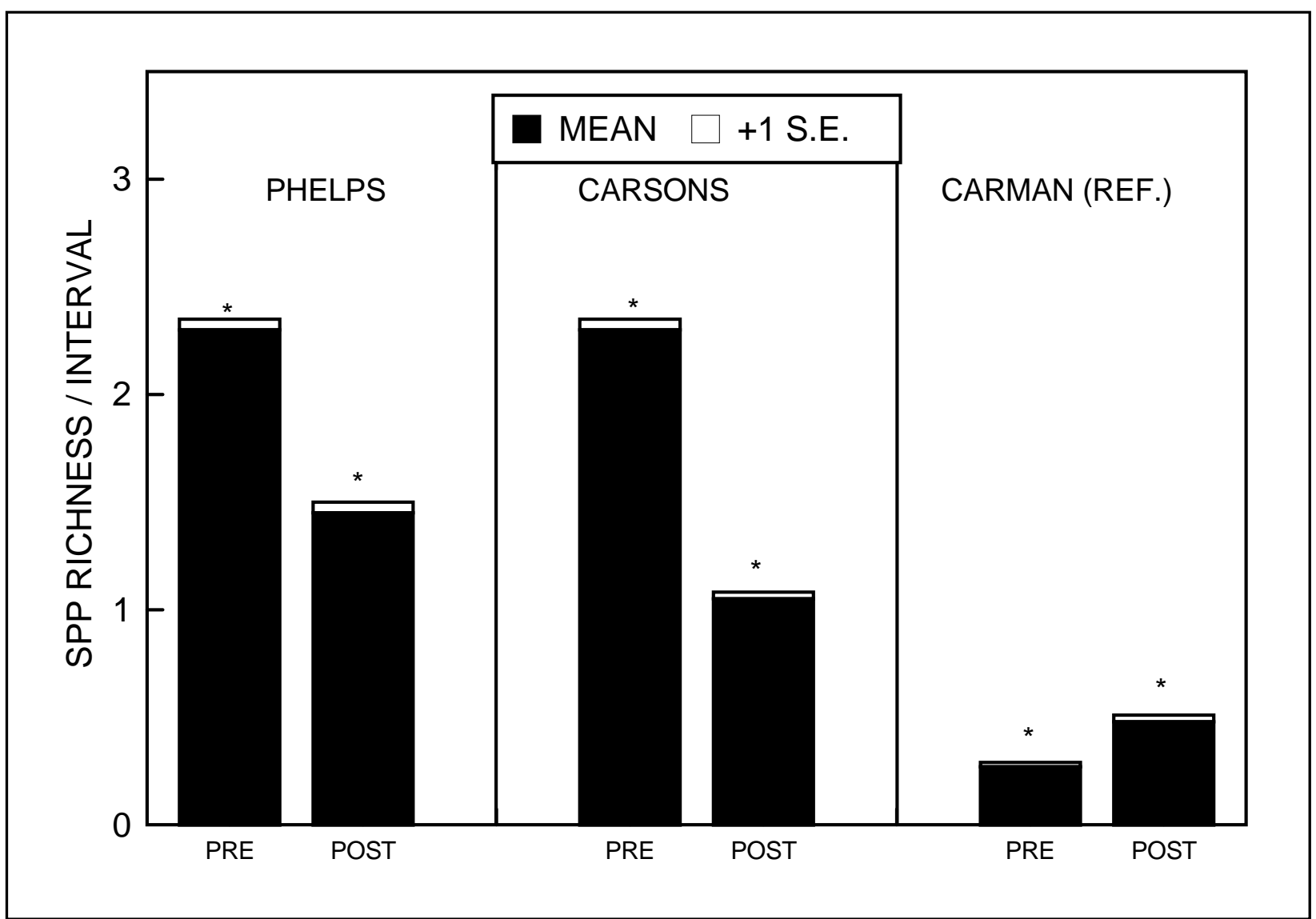

Figure 9. Species richness of native plants as number of species per transect interval pre- (PRE) and posttreatment (POST) at the two treatment sites (PHELPS, CARSON) and the untreated reference (CARMEN (REF.)) site. Asterisks $\left({ }^{*}\right)$ indicate a significant difference between pre- and posttreatment at the $p=0.05$ level using a T-test

POINTS OF CONTACT: This technical note was written by Dr. John D. Madsen of the U.S. Army Engineer Waterways Experiment Station. For additional information, contact Dr. Madsen (601- 634-4631, or madsenj@wes.army.mil), or the managers of the Aquatic Plant Control Research Program, Dr. John Barko (601-634-3654, barkoj@wes.army.mil and Mr. Robert C. Gunkel, Jr., (601-634-3722, gunkelr@wes.army.mil). This technical note should be cited as follows:

Madsen, J. D. (1999). "Point intercept and line intercept methods for aquatic plant management." APCRP Technical Notes Collection (TN APCRP-M1-02). U.S. Army Engineer Research and Development Center, Vicksburg, MS. www.wes.army.mil/el/aqua.

\section{REFERENCES}

American Public Health Association. (1995). "Standard methods for the examination of water and wastewater." $19^{\text {th }}$ ed., Washington, DC.

Bauer, H. L. (1943). "The statistical analysis of chaparral and other plant communities by means of transect samples," Ecology 24, 45-60.

Dennis, W. M., and Isoms, B. G., eds. (1984). "Ecological assessment of macrophyton: Collection, use and meaning of data," ASTM STP 843, American Society for Testing and Materials, Washington, DC. 
Getsinger, K. D., Turner, E. G., Madsen, J. D., and Netherland, M. D. (1997). "Restoring native vegetation in a eurasian water milfoil-dominated plant community using the herbicide Triclopyr," Regulated Rivers: Research \& Management 13, 357-375.

Grieg-Smith, P. (1983). "Quantitative plant ecology.” $3^{\text {rd }}$ ed., Blackwell Scientific Publications, London.

Hellquist, C. B. (1993). "Taxonomic considerations in aquatic vegetation assessments," Lake and Reservoir Management 7, 175-183.

Kershaw, K. A. (1973). "Quantitative and dynamic plant ecology.” $2^{\text {nd }}$ ed., Arnold, London.

Lind, O. T. (1979). "Handbook of common methods in limnology." $2^{\text {nd }}$ ed., ISBN: 0-8016-3019-3, C. V. Mosby Company, St. Louis, MO.

Madsen, J. D. (1993). "Biomass techniques for monitoring and assessing control of aquatic vegetation," Lake and Reservoir Management 7, 141-154.

Madsen, J. D., and Barko, J. W. (1997). “Aquatic vegetation of Big Muskego Lake: 1995 survey,” Letter Report 3, March 1997, U.S. Army Engineer Waterways Experiment Station, Vicksburg, MS.

Madsen, J. D., and Bloomfield, J. A. (1993). “Aquatic Vegetation Quantification Symposium: An Overview,” Lake and Reservoir Management 7, 137-140.

Madsen, J. D., Bloomfield, J. A., Sutherland, J. W., Eichler, L. W., and Boylen, C. W. (1996). "The aquatic macrophyte community of Onondaga Lake: Field survey and plant growth bioassays of lake sediments," Lake and Reservoir Management 12, 73-79.

Madsen, J. D., Dick, G. O., Honnell, D., Shearer, J., and Smart, R. M. (1994). "Ecological assessment of Kirk Pond," Miscellaneous Paper A-94-1, U.S. Army Engineer Waterways Experiment Station, Vicksburg, MS.

Madsen, J. D., Sutherland, J. W., Bloomfield, J. A., Eichler, L. W., and Boylen, C. W. (1991). "The decline of native vegetation under dense Eurasian watermilfoil canopies," Journal of Aquatic Plant Management 29, 94-99.

Schmid, W. P. (1965). "Distribution of aquatic vegetation as measured by line intercept with SCUBA," Ecology 46, 816-823.

Smith, C. S., Barko, J. W., and McFarland, D. G. (1991). "Ecological considerations in the management of Eurasian watermilfoil in Lake Minnetonka, Minnesota," Technical Report A-91-3, U.S. Army Engineer Waterways Experiment Station, Vicksburg, MS.

Snedecor, G. W., and Cochran, W. G. (1980). "Statistical Methods," $7^{\text {th }}$ ed., Iowa State University Press, Ames, IA.

Spencer, D. F., and Whitehand, L. C. (1993). "Experimental design and analysis in field studies of aquatic vegetation," Lake and Reservoir Management 7, 165-174.

Titus, J. E. (1993). “Submersed macrophyte vegetation and distribution within lakes: Line transect sampling," Lake and Reservoir Management 7, 155-164.

Wetzel, R. G., and Likens, G. E. (1991). “Limnological Analyses,” $2^{\text {nd }}$ ed., ISBN: 0-387-97331-1, Springer-Verlag, New York.

White, K. L. (1965). “Shrub-carrs of Southeastern Wisconsin,” Ecology 46, 286-204.

NOTE: The contents of this technical note are not to be used for advertising, publication, or promotional purposes. Citation of trade names does not constitute an official endorsement of approval of the use of such products. 